\title{
Pragmatyzm dzisiaj (ze szczególnym uwzględnieniem propozycji Johna Deweya) a jego korzenie antyczne
}

\section{KEY WORDS}

Dewey's pragmatism, naturalistic empiricism, aesthetic concept, the concept of reconstruction

\begin{abstract}
Chudoba Ewa, Pragmatyzm dzisiaj (ze szczególnym uwzględnieniem propozycii Johna Deweya) a jego korzenie antyczne [Contemporary Pragmatism (With a Special Emphasis on John Dewey's Propositions) and its Antique Roots]. Kultura - Spoleczeństwo - Edukacja nr 2(8) 2015, Poznań 2015, pp. 111-130, Adam Mickiewicz University Press. ISBN 978-83-232-3004-5. ISSN 2300-0422
\end{abstract}

The author of the article poses the following question: Why would we find Dewey's classic pragmatism interesting and is it true that everything that is really important can be found in the works of his followers: Rorty and Shuterman. The author emphasizes that in her narrative she is mostly interested in more primal Dewey whose philosophical thoughts, naturalistic empiricism, as he himself called his philosophy, as well as the aesthetic concepts are not subject to frequent debates in our country. She indicates that there are certain abuses in the interpretation of Dewey's philosophy. One of them is, for example, treating Dewey as a leftist philosopher who has not had much to offer when it comes to the approach to tradition and history. The author emphasizes that although Dewey's point of view was very far from being right-wing or far from accepting nationalism, he is not a left-wing thinker. Dewey is a philosopher who remains extremely attached to tradition and he believes that knowledge about history is crucial to understand philosophy and culture. The author specifically refers to emphasize that Dewey reminds us of what full of life and contemporary art really is. It stems from the rhythm and needs of social life and it expresses beliefs of a given community or society.

1.

Dlaczego dzisiaj klasyczny pragmatyzm Deweya miałby nas interesować? Czy nie wydaje się, że wszystko, co najważniejsze, znajduje się w pracach jego kontynu- 
atorów: Rorty'ego i Shustermana? Prawda jednak wygląda tak, że Dewey Rorty'ego, a przede wszystkim Dewey Shustermana, to Dewey odpowiednio już przefiltrowany. Dewey bardziej interesuje Shustermana jako ogólna inspiracja niż jako partner do dyskusji. Shusterman z Deweyem nie prowadzi polemiki (w krytyce doświadczenia powołuje się na argumentację Rorty'ego; por. Shusterman, 2005: 208-209), wybiera natomiast wątki dla niego atrakcyjne, rozwija je, by całą resztę, często problematyczną, a jeszcze częściej naprawdę oryginalną, zbyć milczeniem. Nie jest Shusterman, co wynika z powyższego, badaczem i interpretatorem filozofii Johna Deweya, a jego bardzo twórczym kontynuatorem.

Nas interesuje Dewey w postaci bardziej pierwotnej, ten Dewey, którego myśl filozoficzna, empiryzm naturalistyczny, jak sam nazywał swoją filozofię, oraz koncepcja estetyczna nie jest w zasadzie szeroko znana w naszym kraju. Śmiem twierdzić nawet, że w powszechnej świadomości Polaków Dewey nie jest obecny jako klasyk filozofii. Warto tę lukę uzupełnić. Co do Shustermana, nie stracimy go z oczu - wszak to on był w ostatnim czasie najzarliwszym promotorem autora Sztuki jako doświadczenia.

Nie musimy szukać u innych autorów metody podejścia do Deweya, gdyż jego filozofia zawiera $\mathrm{w}$ sobie metodologiczną regułę postępowania $\mathrm{z}$ dziełami klasycznymi i historycznymi. Jednym z głównych pojęć filozofii Deweya jest pojęcie rekonstrukcji - nieco, jak się wydaje, dzisiaj zapomniane. To właśnie przy jego użyciu książkę na temat estetyki Deweya napisała propagatorka jego myśli Krystyna Wilkoszewska. Jest to, niestety, odosobniony przypadek. Badacze zdają się o tym pojęciu zapominać, co prowadzi do pewnych nadużyć w interpretowaniu jego filozofii. Jednym $z$ nich jest na przykład potraktowanie Deweya jako filozofa lewicowego, który nie miał wiele do zaproponowania, jeśli chodzi o podejście do tradycji i historii. Jakkolwiek jego światopogląd był jak najdalszy od prawicowości czy akceptacji nacjonalizmu ${ }^{1}$, to jednak nie jest on myślicielem lewicującym. Pozostaje Dewey filozofem niezmiernie do tradycji przywiązanym i przekonanym, że poznanie historii jest kluczowe w rozumieniu filozofii i całej kultury. Tom jego dzieł, zatytułowny Reconstruction in Philosophy and Essays,

\footnotetext{
${ }^{1}$ Swojej niechęci do nacjonalizmu daje Dewey wyraz w Sztuce jako doświadczeniu. Przejawem postawy nacjonalistycznej jest według niego gromadzenie w muzeach i otaczanie się drogimi przedmiotami, które zostały zagrabione innym narodom: „Większość europejskich muzeów to poza wszystkim innym pomniki budzącego się nacjonalizmu i imperializmu" (Dewey, 1975). Trudno odmówić tym słowom trafności, wziąwszy pod uwagę fakt, że byl pisane w latach trzydziestych XX wieku.
} 
poświęcony jest badaniu takich kwestii jak narodziny filozofii ${ }^{2}$, a także wykładowi historii filozofii w ajęciu kulturowo-antropologicznym. Rekonstrukcja jest takim podejściem do zagadnień przeszłości, które wybiera z niej wątki i zagadnienia szczególnie ważne dla badacza i czasów jemu współczesnych. Nie jest to zwykły referat czy prezentacja, ale twórcze wydobycie myśli istotnych dzisiaj. Rekonstruując, reorganizujemy, przeformułowujemy i zmieniamy akcenty tak, by przeszłe zagadnienia nabrały nowego znaczenia; chodzi więc $w$ rekonstrukcji "o nowe uporządkowanie zastanego materiału i w efekcie o modyfikację tradycji” (Wilkoszewska, 1991: 9-10) pod kątem współczesności.

Z jednej strony kwestia rekonstruowania wydaje się oczywista: zawsze przecież problematyzujemy poglądy klasyka z perspektywy naszej, nie da się tego uniknąć (nikt nie będzie się dzisiaj na poważne zajmował tym, co np. Schopenhauer sądził na temat biologii czy geologii, gdyż nie mówi to nam nic ważnego). $Z$ drugiej jednak strony wcale nie jest to kwestia banalna, gdyż wymaga od badacza, co, jak się okazuje, nieraz jest zadaniem nie najłatwiejszym, orientacji w problemach współczesnych, rozeznania w życiu tu i teraz. Do przeprowadzenia rzetelnej rekonstrukcji potrzeba ostrości widzenia spraw dzisiejszych, a przy takich ocenach łatwo można się oczywiście pomylić.

Reasumując: w rekonstrukcji kluczowe jest konstruowanie na nowo myśli już zastanych. Dewey, chociaż jego filozofia ma wydźwięk prospektywny, a więc nastawiony na rozwiązywanie problemów teraźniejszych i przyszłych, nie odwracał się od historii. Uważał, że historia i tradycja mogą nam coś istotnego powiedzieć o nas samych, ale pod jednym warunkiem, tylko i wyłącznie wtedy, kiedy zostaną zrekonstruowane, a więc na nowo sproblematyzowane, a co się $\mathrm{z}$ tym wiąże - włączone w żywy nurt życia. W dziele Deweya zawarta jest tym samym sugestia, żeby myśl jego samego rekonstruować z pożytkiem dla naszej wiedzy i rozważań.

\section{2.}

Badacze lubią ostatnio włączać myśl Deweya w obręb rozważań na temat sztuki życia, odwołując się do filozofii starożytnej. Celują zatem od jakiegoś czasu w rekonstruowaniu pragmatyzmu Deweya pod kątem jego korzeni antycznych,

\footnotetext{
${ }^{2}$ Do tekstu o narodzinach filozofii: Changing Conceptions of Philosophy powrócę jeszcze poniżej.
} 
przywołując, rzecz jasna, książkę Pierre’a Hadota Filozofia jako ćwiczenie duchowe oraz formułę Jamesa, że pragmatyzm to „nowa nazwa dla starych metod myślenia"”, na uzasadnienie tej właśnie inspiracji ${ }^{4}$.

Badacze wskazują na to, że praktykowanie wypracowanych (osobiście bądź przez jakiś nurt myślenia) postaw życiowych i wcielanie przekonań jest tym, co spaja myślenie filozofów starożytnych, pragmatyzm oraz zaspokaja potrzeby współczesnego czlowieka. W czasach zatem, kiedy specjalizacja poszczególnych dziedzin życia jest bardzo wąska, pragmatyzm miałby być współczesną realizacją greckich postulatów dobrego życia.

Jeżeli chodzi o ducha, a nie literę, to analogie między postulatami Deweya a wspominanymi szkołami są zaskakująco odświeżające i brzmią dość atrakcyjnie. Rzeczywiście, pragmatyzm, podobnie jak filozofowie starożytni, kładzie nacisk na jakość życia, realizację swojego ja i generalnie rzecz ujmując, na to, aby żyć rozumnie i w harmonii z sobą i otoczeniem. Słowa Hadota brzmią bardzo pragmatystycznie:

$\mathrm{Z}$ ich punktu widzenia [chodzi oczywiście o hellenistyczne i rzymskie szkoły filozoficzne] filozofia nie polega na nauczaniu oderwanej teorii ani tym bardziej na egzegezie tekstów, ale na sztuce życia, na konkretnej postawie, na określonym stylu życia, angażującym całą egzystencję. Akt filozoficzny nie jest umieszczony jedynie w porządku poznania, lecz równie w porządku "samego siebie" i w porządku istnienia; to akt postępu, który sprawia, że bardziej jesteśmy; który czyni nas lepszymi. (Hadot, 1992: 14)

\section{I dalej:}

Celem, do którego zmierzają wszystkie szkoły filozoficzne - [jest] ulepszenie, realizacja siebie $^{5}$.

Podejście Hadota było rewolucją w myśleniu o filozofii starożytnej, pokazało bowiem z niesłychaną dobitnością, że nie tworzenie systemów i rozumowań samych w sobie, a ćwiczenie się w mądrym życiu było jądrem działalności szkół greckich. Było to odkrycie, którym deweiści się zachwycili. Wszak dokładnie o to samo chodzi w rodzimej filozofii amerykańskiej, jeżeli tak oczywiście można

${ }^{3}$ Tak brzmi podtytuł dzieła W. Jamesa Pragmatyzm.

${ }^{4}$ Tak czyni R. Shusterman w Praktyce filozofii, s. 7.

${ }^{5}$ Hadot, 1992: 45. Wspomiana przez Hadota realizacja siebie nasuwa analogie z koncepcjami psychologicznymi, szczególnie z psychologią humanistyczną Abrahama Maslowa. Szerzej te kwestie omawia Beata Szymańska w Co to znaczy być sobą? Filozoficzne aspekty pojęcia samorealizacji, inspirując się również Hadotem. 
nazwać pragmatyzm. Okazało się tym samym, że pragmatyści mają swoich poprzedników w osobach starożytnych myślicieli oraz że, innymi słowy, ich intuicja obecna była w kulturze Zachodu u samych początków. Jedność wyznawanych przekonań i sposobu funkcjonowania, całkowita zgodność między rodzajem podejmowanej refleksji a działaniami - czy jeszcze szerzej: zgodność między myśleniem a działaniem - stanowi podwaliny filozofii Johna Deweya i całego pragmatyzmu. Te przekonania mają swą dojrzałą realizację w późnej filozofii Johna Deweya (lata trzydzieste XX wieku) na nieco innej niż dotychczas, bo estetycznej, płaszczyźnie.

Jeżeli jednak przyjrzymy się bliżej postulatom starożytnych i pragmatyzmowi Deweya, możemy zauważyć dość istotne różnice, których kontynuatorzy pragmatyzmu, a szczególnie chodzi mi tutaj o Shustermana, nie są skłonni zauważać. Różnice te dotyczą takich kwestii jak: a) generalny charakter propozycji Johna Deweya i przedstawicieli szkół antycznych, b) podejście do materii i natury; rola życia codziennego, c) koncepcja jaźni, d) podejście do kwestii społecznych w tym przypadku Shusterman wiernie oddaje Deweyowską ideę zatracania czy tłumienia własnego ja w imię wyższych celów społecznych (por. Shusterman, 2005: 38), e) koncepcja przyjemności, f) rozumienie estetyczności. Gdy weźmiemy pod uwagę wymienione powyżej obszary różniące oba nurty myślenia, zobaczymy, że pragmatyzm nie tylko nie jest współczesną realizacją postulatów antycznych, ale że ma coś innego i nowego do zaproponowania. Zajmę się, oprócz przedstawienia powyższych punktów, również pewnymi tezami Shustermana, które nie zawsze wydają mi się trafne w odniesieniu do Deweya. Dotyczyć to będzie przede wszystkim potraktowanie propozycji Deweya jako estetycznej odmiany życia filozoficznego (por. Shusterman, 2005: 34). W ujęciu Shustermana istnieje również odmiana medyczna.

Wszystkie wspomniane w punktach kwestie analizować będę na podstawie Sztuki jako doświadczenia, jedynego dzieła Deweya, które przedstawia jego dojrzałą wizję życia ludzkiego w całej złożoności problemu. Pod wieloma względami jest to praca, którą możemy potraktować jako traktat o życiu ludzkim. Koncentruje się w nim Dewey na pokazaniu życia ludzkiego jako potoku doświadczeń oraz na jego zakorzenieniu w naturze. Jest to jedno z jego nielicznych dziel, w którym w całości zajmuje się on problematyką życia ludzkiego - pomijam w tym miejscu dzieła pedagogiczne filozofa. W swoim głównym dziele Experience and Nature Dewey bardziej był skoncentrowany na przedstawieniu swojej wizji natury i życia w sensie biologicznym. Zainteresowania antropologiczne, a następnie refleksja nad sztuką zdominowały natomiast Sztukę jako doświadczenie. 


\section{3.}

W tym miejscu powrócić musimy do wyjaśnienia, dlaczego według nas rekonstruowanie filozofii człowieka Deweya i jego estetyki pod kątem filozofii starożytnej nie jest do końca trafne. Przede wszystkim chodzi o charakter niektórych dzieł starożytnych i o wydźwięk Sztuki jako doświadczenia. Dzieło Deweya, w przeciwieństwie do tekstów starożytnych przedstawicieli różnorakich szkół mądrego życia, nie ma charakteru postulatywnego, mądrościowego, nie jest, innymi słowy, przewodnikiem czy poradnikiem, jak żyć dobrze. Dewey nie odpowiada na żadne pytanie w rodzaju: jak żyć? Filozof amerykański życie po prostu opisuje. Przedstawia w wielu miejscach swoje przekonanie co do ciągłego i rytmicznego charakteru potoku życia, a następnie jasno formułuje przeświadczenie o jego zakorzenieniu w przyrodzie, a także o cechach charakterystycznych, które dzielimy ze zwierzętami - chodzi przede wszystkim o całkowitą jedność zmysłów, czucia, wyobraźni, intelektu i działania. Odwołuje się na poparcie niektórych swoich tez do utworów poetyckich, snuje interesujące metafory itd., ale nigdy nie wskazuje, co mamy robić, żeby osiągnąć radość, szczęście i mądrość itd. Idźmy jednak dalej. Ogólny wydźwięk nie decyduje ostatecznie o tym, że filozofia Deweya nie jest współczesną realizacją myślenia antycznego.

Główną sprawą, która różni Deweya od filozofów starożytnych, jest podejście do spraw materii, życia codziennego i natury. Przede wszystkim przedstawiciele szkół greckich nie mieli afirmującego stosunku do materii i spraw praktycznych. Manipulacja materią - przedmiotami, substancjami i narzędziami - była domeną niewolników i rzemieślników, stojących w hierarchii społecznej nieco tylko wyżej od tych pierwszych. Nie wolno zapominać, że system obywatelski Aten ufundowany był na niewolnictwie. Filozofowie - ateńscy obywatele - mogli zatem bez trosk o sprawy doczesne i zmienne zajmować się ćwiczeniami duchowymi i pracą nad sobą. Postulaty filozofów starożytnych szły jednak znacznie dalej niż odrzucenie zajmowania się sprawami związanymi z walką z materią.

Ideałem szkół greckich, wyjąwszy cyników, było maksymalne uniezależnienie się od problemów stawianych przez błahe sprawy codzienne. W pierwszym rzędzie adept szkoły musiał nauczyć się wygaszania w sobie wszelkich namiętności, które mogłyby go kierować ku zmiennemu potokowi życia. Pierwsza faza ćwiczeń duchowych była zawsze negatywna: pozbyć się trosk niezależnych od nas, wytrzebić namiętności. Pragmatyzm natomiast jest afirmacją codzienności z jej powszedniością i banalnością nawet, jest celebrowaniem osobistych, pry- 
watnych rytuałów, które przynoszą nam radość z interakcji ze środowiskiem i z narzędziami, którymi się posługujemy. Zwróćmy uwagę na poniższy cytat:

Do zrozumienia, które stara się osiągnąć teoria, dotrzemy drogą okrężną, przez zwrócenie się $\mathrm{z}$ powrotem do tego, co powszechne, powszednie i przeciętne, aby w ten sposób dotrzeć do estetycznych jakości zawartych w zwykłym doświadczeniu. (Dewey, 1975: 14)

Dewey nie rezygnuje zatem $z$ roli i funkcji, jaką pełni w życiu doświadczenie potoczne. Od niego bowiem wszelkie doświadczenie się w ogóle zaczyna i nie ma innej drogi w poznawaniu i doznawaniu świata, jak tylko poprzez sprawy codzienne. Jest również sprawą niezwykłej wagi, że uciec od problematyki życia codziennego we współczesnym świecie niepodobna. Co więcej, nawet osoba, która odrzuci codzienność, powszedniość i zwyczajność, a w konsekwencji nie będzie jej akceptować, nigdy nie osiągnie spełnienia, a więc nie odczuje życia w jego wysublimowanej i zintensyfikowanej postaci. Chwile niecodzienne są bowiem częścią codzienności. Negując je, postępuje tak, jakby negowała fakt, żeby posłużyć się metaforą Deweya, że szczyty górskie są częścią ziemi. Dewey pisze: „Szczyty górskie nie pływają w przestworzach, oderwane od podłoża, ani nawet nie wznoszą się na powierzchni ziemi. One są ziemią w jednym z jej widocznych przejawów" (Dewey, 1975: 6).

Filozofowie greccy dążyli do ograniczenia do minimum posługiwania się narzędziami czy współdziałania z ludźmi w ogóle. Tłum, społeczeństwo jako całość nie było pozytywnie waloryzowane. Owszem, filozofowie chcieli mieć wpływ na strukturę społeczną i na politykę, ale duch współdziałania $z$ „klasą pracującą” był im całkowicie obcy. Urządzenia społeczne, życie społeczne było ponadto dla filozofów grą namiętności, od której w miarę możliwości należało się zdystansować. Sterować społeczeństwem odgórnie - było ich ideałem, ale uczestnictwo w jego sprawach powszednich - czymś nie do przyjęcia. Przedstawiciele szkół greckich tworzyli raczej coś w rodzaju intelektualnych gett, elitarnych stowarzyszeń, które ćwiczyły się we wspólnym dialogu i w raz obranej drodze duchowej.

Po przejściu etapu negatywnego w ćwiczeniach duchowych następowało przygotowywanie do celu najwyższego, którym była kontemplacja natury. Ta natura zatem, z którą niewolnicy musieli się uporać, aby dostarczać np. filozofom żywność, miała zupełnie inne znaczenie - była przedmiotem kontemplacji właśnie. Życie adepta filozofii podporządkowane było przemianie, konwersji, jak pisze Hadot (1992: 47), aby stało się w efekcie kontemplacją wszechrzeczy. Relacja do natury oparta była zatem na postawie zdystansowanej. 
W pragmatyzmie stosunek do materii, natury i spraw praktycznych wynika ze stosunku do życia codziennego. Człowiek nieustannie znajduje się w relacjach z naturą i otoczeniem, stale ma do czynienia z narzędziami i przedmiotami, a także stale wykorzystuje te czy inne umiejętności praktyczne. Pozytywne waloryzowanie interakcji z materią, przyrodą i kładzenie nacisku na rolę działania w życiu ma być może związek z podejściem pierwszych osadników amerykańskiej do ziemi w Nowym Świecie (por. Wilkoszewska, 1991: 49) i ze strukturą społeczną wtedy panującą. Pierwsi osadnicy zdani byli tylko i wyłącznie na siebie: ten, kto z większą energią oddawał się przystosowywaniu dzikiej natury do warunków życia, miał większe szanse na sukces życiowy. W biografii Izaaka Merritta Singera, wynalazcy oraz konstruktora słynnej maszyny do szycia nazwanej jego nazwiskiem, autorstwa Ruth Brandon, znajdziemy opis Ameryki z pierwszej połowy i z połowy dziewiętnastego wieku, który może nieco pomóc w zrozumieniu specyfiki, w jakiej rodziła się filozofia amerykańska. Pierwsze doświadczenia $z$ nowym kontynentem były dość brutalne: wymagał on pracy, fizycznego wysiłku, aby mógł stać się miejscem cywilizowanym, a więc takim, w którym kultura może na stałe zagościć. Kultura w tym przypadku zależna była od agrokultury. Autorka monografii pisze o warunkach zastanych, co następuje:

\footnotetext{
Rzeczywiście, pomimo pogodnych zapewnien wielu ówczesnych podręczników dla imigrantów, życie w Ameryce dla wszystkich, którzy go zakosztowali, dalekie było od zapewnianej sielanki. Autorzy podręczników nie wspominają, że chociaż warunki do rozwoju były sprzyjające, nie wszyscy potrafili nich skorzystać. Dziewicza ziemia była tania (...), ale rola pioniera, zmienianie dzikich terenów $w$ farmy, to zadanie niezwykle trudne, wymagające olbrzymiego uporu, gotowości błyskawicznego przystosowania się do zmiennych warunków i wielu praktycznych umiejętności. (Brandon, 2006: 17-18. Rozdział nosi interesujący tytuł Pierwsze doświadczenia)
}

Jest zastanawiające, że autorka wymienia wśród czynników kluczowych takie jak gotowość przystosowania się do zmiennych warunków. Tą kwestią zajmuje się John Dewey i to w dziele szczególnie nas interesującym: w Sztuce jako doświadczeniu. Filozof uważa, że przystosowanie się do otoczenia i w konsekwencji życie w harmonii z nim jest podstawowym sposobem funkcjonowania jednostek, a także podstawą ich rozwoju. Człowiek bowiem - w tym miejscu snuje Dewey analogię do organizmu żywego - który nie przystosuje się do środowiska, po prostu zginie: „Jeśli rozdźwięk między ustrojem a otoczeniem jest zbyt wielki, następuje śmierć" (Dewey, 1975: 18). A im owo przystosowanie jest bardziej efektywne, tym człowiek ma większą szansę odczuwać spełnienie, a w dalszym 
rzędzie szczęście. Interakcja ze środowiskiem jest stanem ustawicznym: każde przystosowanie ulega, choćby nawet częściowemu, zachwianiu; dzieje się tak dlatego, że natura, środowisko, w tym otoczenie ludzkie, chociaż wytwarza twory stałe, to jednak ulega ciągłym zmianom. Raz ukształtowany aspekt rzeczywistości podlega kolejnym interakcjom na wyższym poziomie - tym samym zmienia się. I również to metafizyczne przekonanie o zmienności wszystkiego ma swoje praktyczne korzenie w sposobie funkcjonowaniu pionierów i ich potomków. Brandon pisze:

(...) Isaac (Singer) był pod wieloma względami typowym człowiekiem swojej epoki. Był niespokojnym duchem, a wczesna dziewiętnastowieczna Ameryka była niespokojnym miejscem. Gonił za nowością, w kraju, gdzie „nowszy” znaczy „lepszy”. Nie potrafił się ustatkować i przywiązać do niczego, ale taka umiejętność nie była jeszcze warunkiem dobrego życia, którym miała się stać później - a zwłaszcza nie była nim w Ameryce. Bo w Nowym Świecie wszystko było w ruchu. (Brandon, 2006: 23)

Interakcja i zmiana jest podstawowym pojęciem całej filozofii Deweya, podobnie jak doświadczenie. Wracając do porównania ze szkołami greckimi, należy powiedzieć, że natura nie jest dla Deweya kontemplacyjnym punktem dojścia, ale punktem wyjścia - to bowiem $z$ niej na drodze skomplikowanych przekształceń ewolucyjnych, które możemy określić jako łańcuch interakcji, a następnie doświadczeń między organizmami lub też między organizmami a środowiskiem, wyłania się jaźń, a wraz z nią refleksja. Praca fizyczna i umiejętności praktyczne mają istotne znaczenie w pochodzie zmian i rozwoju. Początki wszelkiego myślenia 'pozytywistycznego' mają bowiem źródło w prostych reakcjach i czynnościach praktycznych ${ }^{6}$, które stanowiły odpowiedź na nieokreślone sytuacje problemowe. U Deweya natura i materia towarzyszą człowiekowi stale w zmiennym nurcie życia codziennego, tak jak towarzyszyła pierwszym osadnikom amerykańskim. Środowisko naturalne człowieka ukształtowało i nadal go kształtuje, w dobie dzisiejszej bardziej już jako otoczenie najbliższe - dla Deweya jest otoczenie, podobnie jak kultura, która wyłania się z natury na mocy działalności człowieka, zawsze naturalne.

\footnotetext{
${ }^{6}$ Daje temu przekonaniu Dewey wyraz między innymi w tekście na temat powstania filozofii. Ukazuje tam genezę racjonalnego myślenia. Pisze, co następuje: "This knowledge (about observed facts and sequences of nature) is especially connected with industries, arts, crafts where observation of materials and processes is required for successful action (...)" (Dewey, 1988: 85) i dalej: "As the arts and the crafts develop and become more elaborated, the body of positive and tested knowledge enlarges, and the sequences observed become more complex and of greater scope" (Dewey, 1988: 86).
} 
Dewey w zagadnieniach życia społecznego jest demokratą. Nie ma w jego filozofii żadnych podziałów: każdy uczestniczy w pochodzie doświadczenia, każdy może kształtować swoje życie i podnosić jego jakość. Inna też niż u starożytnych jest koncepcja jaźni: według Deweya jaźń rodzi się w interakcjach między organizmami żywymi a naturą; następnie osobowość kształtuje się w nieskończonych interakcjach społecznych, rodzi się w międzyludzkich uwikłaniach i dzięki nim uzyskuje wyrazistość. Podnoszenie jakości naszego życia nie ma tylko wydźwięku jednostkowego; zmiana ta, jako że egzystencja ludzka jest rozpostarta w interakcyjnych relacjach, powoduje zmiany w tychże relacjach, ma zatem wymiar społeczny. Można czasem odnieść wrażenie, że w filozofii Deweya ja poświęcone jest na ołtarzu społeczeństwa i dobra publicznego, ale sam Dewey miał do takiego ujęcia pozytywny stosunek - być może jest to również powód, dla którego jego filozofia cieszy się taką popularnością na Dalekim Wschodzie ${ }^{7}$. U filozofów starożytnych jaźń jest już ukształtowana i sama jest jądrem przemiany. Dyskusje, dialogi - wszak cała filozofia starożytna jest oparta na dialogu i wymianie myśl są siłą napędową, niejako motorem narodzin prawdziwego człowieka. Rozmowa jest rozumiana jako wymiana myśli właśnie, jako ćwiczenie istniejących już jaźni i poddawanie tych jaźni przemianie, lecz konwersja nie ma wymiaru społecznego.

U Deweya, jak wspomniałam powyżej, interakcje jaźń najpierw konstytuują w warstwie ontologicznej. Na poziomie, na którym mówimy o jakości życia, jaźń jest już ukształtowana, jednak połączona jest nadal siecią interakcji i zależności z najbliższym otoczeniem - środowiskiem ludzkim. Wszelka zmiana w jaźni znajduje swoją kontynuację w życiu społecznym. Podnosząc jakość naszego życia, podnosimy jakość relacji społecznych. Każda zmiana jest natychmiast odczuwana w całym systemie, w którym funkcjonuje człowiek. Zmiany, którym podlega człowick, niejednokrotnie są właśnie inspirowane zmianami zewnętrznymi, ale i nie tylko. Człowiek może oczywiście zmienić się, zacząć bardziej odczuwać otaczający go świat, percypować ostrzej, działań wydajniej. Charakter jednak tej zmiany na gruncie pragmatyzmu ma inny charakter i specyfikę niż w filozofii starożytnych. W pragmatyzmie owa zmiana nie jest doprowadzona do ekstremów przemiany, nie jest konwersją. Odbywa się ona stopniowo. Życie autentyczne to życie naturalne, czyli w zgodzie wewnętrznym rytmem każdego $z$ nas (rytm jest pojęciem kluczowym w estetyce Deweya). Zmiana to przede wszystkim ustawiczny rozwój, taki w dodatku, który radzi sobie z przeciwno-

${ }^{7}$ Wszystkie 37 tomów dziel Deweya zostało przetłumaczonych na język chiński. Por. Hickman, 2007. 
ściami, a nawet intensyfikuje się po pokonaniu niedogodności. Pragmatyczne życie nie jest życiem natężonym czy rozdartym jak życie filozofów starożytnych (por. Hadot, 1992: 47), ale spaja wszystkie aspekty ludzkiej egzystencji. Harmonia, rytm, interakcja, ewolucja, przekształcanie, współdziałanie - to pojęcia kluczowe w filozofii Deweya. Był on przede wszystkim darwinistą. To nie Grecy, a Darwin zainspirowali go do postrzegania rzeczywistości jako łańcucha działań wynikających $\mathrm{z}$ namysłu nad praktycznymi kwestiami problematycznymi. Zbieżność myślenia Deweya i Greków zachwyca nas dzisiaj bardzo, jednak trzeba zdać sobie sprawę z tego, że Grecy nie byli w tym względzie inspiracją dla Deweya. Należałoby powiedzieć nawet coś więcej: to u Greków zapoczątkowany został pewien model myślenia, z którym Dewey walczył, a mianowicie kontemplacja i czysta teoria. Estetyka Deweya znosi pojęcia kontemplacji, ponieważ przedmiot i podmiot są zawsze zjednoczone $w$ interakcji, co więcej, $z$ interakcji wyłaniają się w toku ewolucji.

Wniosek z powyższych rozważań jest taki, że Dewey przy tworzeniu swojej koncepcji inspirował się darwinizmem i mówienie o antycznych korzeniach pragmatyzmu jest pewnego rodzaju nadużyciem, które jednakowoż możemy na potrzeby popularyzowania tego nurtu zaakceptować. Każdy jednak badacz, który będzie chciał bliżej zapoznać się z koncepcją Deweya, musi zdać sobie sprawę z realnej roli, jaką odgrywała Grecja w myśleniu Deweya, o czym jeszcze poniżej. Pamiętać również trzeba, że każda refleksja, łącznie z tą na temat naszego życia, którą podejmujemy, jest na gruncie pragmatyzmu uwikłana w kontekst kulturowy, społeczny, cywilizacyjny (por. Kaczocha, 1987: 61-76), ba, technologiczny (por. Hickman, 2007) nawet - i to jest czynnik, który sprawia, że koncepcja kształtowania swojego życia ma zupełnie inny wydźwięk niż greckie ćwiczenia duchowe, ukazuje również dobitnie, ile w kwestiach rozbieżności zrobił upływ czasu. Nie da się sprowadzić pragmatyzmu do antycznych ćwiczeń duchowych. Koncepcja Deweya nie ma charakteru postulatywnego, nie znajdziemy w niej również wskazówek co do tego, jak należy swoje życie zmienić, aby realizować swoje głębokie ja. Co więcej, wydaje się, że nie można takich postulatów sformułować - każdy sam wypracowuje sobie własny rytm funkcjonowania, każdy sam wie, co intensyfikuje jego odczuwanie życia i nie można się tego odgórnie nauczyć.

Różnica ze starożytnymi widoczna jest również w postrzeganiu i interpretowaniu figury Sokratesa. Dla starożytnych był on archetypiczną figurą, osobą godną naśladowania, wierną do końca raz obranej drodze życiowej. Znamienny 
jest sposób, w jaki Dewey interpretuje figurę Sokratesa - pierwszego filozofa w pełnym znaczeniu tego słowa. Według Deweya życie Sokratesa musiało się skończyć w tak tragiczny sposób, ponieważ jego wysiłki zmierzające do pogodzenia dwóch światów: tradycji, obyczaju i wierzeń, nad którym pieczę mieli kapłani i warstwy uprzywilejowane, z myślą rodzącą się z działań praktycznych niewolników i rzemieślników (Dewey, 1988: 87), domagającą się szukania uzasadniania dla wszelkich wierzeń, tradycji, okazały się niemożliwe do realizacji. Wysiłki te zostały poświęcone w ofierze na rzecz dobra publicznego, czyli utrzymania dawnego porządku. Niemniej śmierć Sokratesa pchnęła filozofię na nowe tory - dwa wspomniane światy i klasy miały oddalać się od siebie coraz bardziej, czyli pójść w kierunku diametralnie innym niż sugerował to Sokrates. W ujęciu Hadota postępowanie Sokratesa było wynikiem jego drogi życiowej, jego najradykalniejszą konsekwencją. Dla Deweya Sokrates był pierwszym filozofem, który dążył do uzasadniania wierzeń i przekonań tradycyjnych, który szukał rozumowych wyjaśnień i który chciał pogodzić dawne obyczaje i wierzenia z rodzącą się racjonalnością. Oczywiście ujęcie starożytnych via Hadot i ujęcie Deweya nie są nie do pogodzenia, wyraźnie jednak pokazują różnice między pragmatyzmem a koncepcją filozofów starożytnych. Gdyby Dewey inspirował się Grecją w tworzeniu swojej filozofii człowieka, być może i figura Sokratesa byłaby dla niego wzorem. Ale tak się nigdy nie stało: Sokrates jest pierwszym filozofem, ale nie autorytetem, jeśli chodzi o współczesne życie codzienne z jego problemami. Może to zabrzmi nieco szokująco dla osób, które nie czytały Sztuki jako doświadczenia, ale wydaje się, że życie zwierząt było dla Deweya wzorcem, jeśli chodzi o jedność i spójność istnienia (por. Dewey, 1975: 29, 32). Być może jest to też jedna z przyczyn, dla których rozwija się estetyka zwierząt - właśnie na bazie filozofii Deweya. To zwierzęta wykazują całkowite zespolenie odczuwania, zmysłów, intelektu i działania - ideał dla współczesnego człowieka, którego życie uległo podzieleniu na różnorakie, niemające ze sobą związku dziedziny: w jednej przegródce znajduje się polityka, w drugiej religia, w jeszcze innej sztuka itd. To podzielenie sprawia, że oddzielamy praktyczną działalność od uczuć religijnych, tę od przekonań politycznych, a te od wrażeń estetyczno-artystycznych. Dewey bardzo nad tym ubolewał i wskazywał, że tylko harmonijne życie codzienne, czerpanie radości z codziennych rytuałów, niezaprzeczanie swoim potrzebom może bardzo powoli scalać życie ludzkie.

Na koniec w części poświęconej punktowaniu rozbieżności nie sposób pominąć kategorii przyjemności. Jednym z celów adeptów szkół greckich było od- 
czuwanie przyjemności z samego faktu istnienia; dotyczyło to przede wszystkim epikurejczyków. Życie samo miało dostarczać niekończącej się rozkoszy. Początkowo sądziłam, że podobną intuicję znaleźć możemy u Deweya. Po zastanowieniu jednak dochodzę do wniosku, że Dewey w ogóle się kategorią przyjemności nie kierował (por. Kaczocha, 1987: 64). Przede wszystkim rozumiał przyjemność jako jednorazowe zaspokojenie potrzeby lub wyładowanie nagromadzonych emocji, np. złości. Przygodne przyjemności nie mają większego znaczenia w pochodzeniu życia i nie są gwarantem spełnienia. Tylko ekspresja, a więc interakcja o wysokim znaczeniu, przesiąknięta znaczeniami estetycznym, prowadzi do spełnienia. Spełnienie jest kategorią bazującą na pojęciu rozwoju i harmonii - to długotrwałe zadowolenie ze sposobu życia, które posiada swoiste kulminacje w doświadczeniu estetycznym. Drugim powodem, dla którego przyjemność w rozumieniu starożytnych nie jest kategorią stosowaną przez Deweya, jest jego instrumentalizm. Potok życia składa się z łańcucha celów, które stawia sobie człowiek lub/i nakłada na niego otoczenie. Po osiągnięciu jednego celu natychmiast wyłania się następny. Nie jest to jednak błędne koło, które prowadzi do wyobcowania, dlatego że życie w zgodzie z sobą i naszym wewnętrznym rytmem, a w związku z tym wysoka jakość życia sprawia, że cele zlewają się ze środkami tak dzieje się w doświadczeniach estetycznych. Życie w ujęciu Deweya nie jest wyzerowaniem namiętności i czerpaniem niczym niezmąconej przyjemności z samego faktu, że się istnieje. Namiętności wyzerować nie sposób, zawsze bowiem różnorakie sytuacje sprawią, że człowiek stanie przed nowymi celami, a następnie będzie dążyć do ich zrealizowania. Żyjemy z innymi ludźmi w społeczeństwie, stale znajdujemy się w jakichś sytuacjach, które do czegoś prowadzą. Stałe dążenie od minusa, czyli od sytuacji niesprzyjającej, do plusa, czyli ponownej harmonii z otoczeniem, jest faktem. Spełnienie osiągamy wtedy, kiedy w interakcyjnej sieci poruszamy się harmonijnie, kiedy się w niej rozwijamy jako jednostki i jako członkowie społeczności. Potwierdzeniem spełnienia są doświadczenia estetyczne, w których następuje zrównanie celów ze środkami. Życie to ciągła fluktuacja, zmiana - nie można zatem na gruncie filozofii Deweya mówić o niczym niezmąconej przyjemności $z$ istnienia, zawsze bowiem to istnienie ulegnie zachwianiu, może się zdarzyć, że jakaś potrzeba zdominuje nasze życie itd. Przeciwności losu i niepowodzenia są realnymi sytuacjami, które zawsze należy brać pod uwagę.

Shusterman w swoim opracowaniu koncepcji życia filozoficznego w odniesieniu do filozofii Johna Deweya (trzeba w tym miejscu zaznaczyć, że termin 
„życie filozoficzne” został utworzony przez Shustermana, sam Dewey nigdy i nigdzie go nie stosuje) zalicza koncepcję Deweya do nurtu estetycznego, czyli takiego, w którym traktuje się życie człowieka jako dzieło sztuki (Shusterman, 2005: 33-35). Śmiem twierdzić, że takie postawienie sprawy nie jest całkiem adekwatne w odniesieniu do filozofii autora Experience and Nature. Przede wszystkim należy wyjaśnić, co przez dzieło sztuki rozumie sam Dewey, i wtedy stanie się jasne, że $\mathrm{w}$ tradycyjnym rozumieniu ów postulat życie $=$ dzieło sztuki nie może być zastosowany do jego koncepcji.

Przede wszystkim Dewey rozumie dzieło sztuki nie jako wytwór skończony, określony i zamknięty w swoistej formie, który określa wyjątkowość, genialność jego twórcy. Innymi słowy dzieło sztuki nie jest przedmiotem, produktem sztuki. Jest ono przede wszystkim procesem, a dokładniej doświadczeniem między twórcą a odbiorcą lub między twórcą a tworzywem, który on wykorzystuje (u Deweya nie ma tradycyjnego rozróżnienia między tym, co estetyczne, a tym, co artystyczne). Jest przeżyciem, odczuciem, które ma unifikującą jakość, zespalającą wszystkie elementy tego doświadczenia w spójny, rytmiczny i harmonijny przebieg. Zjednoczeniu ulegają i czynniki zależne od odbiorcy, i od twórcy lub od twórcy i tworzywa. Nie jest zatem sztuka jakimś subiektywnym jednorazowym wzlotem niekomunikowalnych uczuć, ale obiektywnym działaniem i doznawaniem jasnym i czytelnym dla wszystkim stron, biorących w tym doświadczeniu udział. W ujęciu Deweya życie nie może być postrzegane jako dzieło sztuki w takim rozumieniu, w jakim ta fraza pojawiała się raz po raz w historii myśli, szczególnie zaś pod koniec dziewiętnastego wieku, kiedy idea ta przeżywała swój renesans. Sztuka była postrzegana jako rodzaj religii, artyści byli jej kapłanami, zwykli ludzie - filistrami niegodnymi tego, żeby zwracać na nich uwagę. Artysta był postrzegany jako geniusz tworzący piękno. W tradycyjnym rozumieniu życie, które jest dziełem sztuki, ma być wyjątkowe, genialne, nieprzeciętne, wzbijające się na takie wyżyny, które widzą codzienność jako godną pogardy. Cała specyfika tego myślenia była obca Deweyowi. Jak wiemy, według niego życie obejmuje zarówno chwile banalne i powszednie, jak również ich sublimację w doświadczeniach mających szczególną jakość zespalającą i szczególną intensywność. Nie da się życia pociąć, sfragmentaryzować tak, żeby brać pod uwagę tylko chwile estetycznie doniosłe. Życie to całość: to przenikanie się elementów wzmagających nasze odczuwanie życia, jak i momentów walki, radzenia sobie z przeciwnościami oraz chwil banalnych, nie mających żadnego znaczenia. A dziełem sztuki, sztuką, są tylko chwile szczególne. Sztuka według Deweya jest 
doświadczeniem specyficznego typu i, niestety, nie można jej utożsamić z całym życiem, jakkolwiek niemal w każdej sytuacji tkwią zalążki estetyczności. Shusterman zaliczył koncepcję życia Deweya do koncepcji estetycznych. Estetyczność jednak rozumiał Dewey w dość swoisty sposób. To, co estetyczne, nie jest ściśle związane ze sztuką. W pierwszym znaczeniu jakość estetyczna to przede wszystkim jakość, która 1) ma znaczenie, a w związku z tym 2) intensyfikuje odczuwanie życia. Podaje Dewey dość zaskakujące przykłady zdarzeń, które mają pewną jakość estetyczną - jest to np. łowienie ryb i ich smażenie (Dewey, 1975: 34). Czy czynność tak specyficzna - może być choć trochę estetyczna? W rozumieniu Deweya - tak, jeśli niesie szczególne znaczenie dla czyjegoś życia. Dopiero w drugim znaczeniu jakość estetyczna odnosi się do sfery związanej z działaniami artystów i produktami sztuki. Świetnie wykonany koncert, interesujący obraz ma jakość estetyczną, która może być sztuką, jeśli odpowiednie warunki po stronie odbiorcy zostaną spełnione (koncentracja, intensyfikacja percepcji i zawężenie jej pola itd.).

Na koniec powróćmy jednak do rozważań na temat: filozofia starożytna a pragmatyzm Deweya. Oba nurty lączy doznawanie doświadczeń pierwotnych. Jak wspomniałam wyżej: jeżeli chodzi o literę, to zestawianie Deweya ze szkołami greckimi nie wypada korzystnie. Pozostaje jednak coś takiego, jak globalne i ogólne związki - w ujęciu generalnym można do pewnego stopnia mówić o duchowym powinowactwie Deweya i myślicieli starożytnych. I jest ku temu jeden ważny powód: zarówno Dewey, jak i starożytni pragnęli, aby podmiot zespolił się całkowicie z przedmiotem, uzyskał jedność, w której żadne podziały nie mają miejsca. Zaznaczmy jednak na wstępie różnice: według Deweya podmiot i przedmiot w rzeczywistości pierwotnej, przedjęzykowej, były zespolone, dalej w toku ewolucji nastąpiło wyodrębnienie podmiotu i przedmiotu. Co jest jednak szczególnie ważne, podmiot i przedmiot zawsze ze sobą współdziałają; myślenie zawsze jest na usługach działań praktycznych, one nieodmiennie współdziałają ze sobą $\mathrm{w}$ interakcji i doświadczeniu. W filozofii starożytnej dualizm między działaniem a praktyką był po prostu rozziewem, przepaścią nie do pogodzenia. Ćwiczenia duchowe miały sprawić, że: „Widzący nie widzi już przedmiotu swojego widzenia, ponieważ w tym momencie nie różni się od niego; nie ma już przed oczyma dwu rzeczy, stał się w pewien sposób inny, nie jest już sobą ani dla siebie, ale stanowi jedno $\mathrm{z}$ Jednią, tak jak środek koła zbiega się $\mathrm{z}$ innym środkiem" (Hadot, 1992: 44). 
Do podobnego, ale nie tak całkowitego, zjednoczenia podmiotu i przedmiotu dochodzi w Deweyowskim doświadczeniu estetycznym, a więc doświadczeniu pełni i spełnienia na obszarze estetyczno-artystycznym. Doświadczenie takie jest powtórzeniem pierwotnej jedności z poziomu przedjęzykowego, a zależy ono od sposobu, w jaki odczuwamy świat, percypujemy, radzimy sobie z przeciwnościami, od wewnętrznego rytmu życia i rozwoju. Na gruncie filozofii starożytnej owa jednia zależy od dość restrykcyjnych ćwiczeń duchowych, wygaszenia namiętności i czasu poświęconego na kontemplację. W przypadku Deweya i starożytnych mamy zatem dwie drogi dojścia do dość podobnego celu.

\section{4.}

Wszystko można o Johnie Deweyu powiedzieć, ale nie to, że nie był miłośnikiem starożytnej Grecji. Dewey nie tylko znał grekę i jej nauczał, ale fascynował się jej historią, obyczajami, kulturą i religią. We wszystkich swoich największych dziełach - w Experience and Nature, Sztuka jako doświadczenie, Reconstruction in Philosophy - starożytna Grecja jest punktem wyjścia, najróżniejsze przejawy tej cywilizacji są przez Deweya analizowane z niezwykłą pasją na wielu stronach, a problemy filozofii współczesnej i nowożytnej są zawsze rekonstruowane po pierwsze z perspektywy antropologicznej, uwzględniającej funkcjonowanie społeczeństw pierwotnych (mogą oczywiście nas te rozważania bawić, niemniej w swej pasji do wywodzenia wszystkiego od pierwocin jest Dewey niestrudzony: Hobbesowska wizja brutalnego życia ludów pierwotnych nieraz pojawia się kartach jego dzieł) lub poprzez analogie ze światem zwierząt, po drugie z uwzględnieniem tego, co do naszej sytuacji obecnej wniosła cywilizacja starożytnej Grecji. Filozofia grecka, jak żadna inna, jest leitmotivem rozważań Deweya.

Do Grecji, co może pomóc nam w rozumieniu zbieżności i rozbieżności między pragmatyzmem a szkołami antycznymi, miał Dewey jako filozof stosunek ambiwalentny. $Z$ jednej strony społeczeństwo obywatelskie Aten było modelowym przykładem społeczeństwa, w którym sztuka wynikała z nurtu życia i stanowiła zaspokojenie potrzeb jego większej części. Jako przykład Dewey podaje Partenon, wzniesiony jako wyraz postawy Ateńczyków, których zmysł obywatelski był identyczny z ich obywatelską religią (Dewey, 1975: 7). W tym miejscu oczywiście Dewey nie pisze o niewolnictwie, ale to bez wątpienia niewolnicy byli siłą roboczą. Partenon dla całego społeczeństwa był źródłem znaczeń z wykluczeniem niewolników właśnie. Pomijając tę niekoherencję - jeżeli chodzi 
o sztukę, byli Ateńczycy wzorem społeczeństwa potrafiącego zaspokoić swoje potrzeby estetyczne. Innymi słowy, była ich sztuka zespolona z życiem. Jest zatem w pełni zrozumiałe, dlaczego Grecy stworzyli koncepcję mimesis: sztuka tak ściśle związana z życiem koncentruje się na oddawaniu jego cech i jakości. Dla kontrastu z Ateńczykami Dewey prezentuje współczesne społeczeństwo amerykańskie, które nie potrafi wytworzyć sztuki estetycznie - w rozumieniu drugim ważnej (potrzeby estetyczne Amerykanie zaspokajają, czytając komiksy i słuchając muzyki popularnej - pamiętajmy o tym, że w pierwszym znaczeniu estetyczny oznacza mający znaczenie), a potrafi jedynie koncentrować w galeriach i muzeach sztukę innych narodów, która, wyzuta z pierwotnego kontekstu, jest obca i niezrozumiała, a w związku z tym zaspokaja tylko snobistyczną potrzebę wydawania pieniędzy.

Z drugiej strony, jeżeli idzie o filozofię, Grecy wytworzyli podziały, które do dzisiaj pokutują w filozofii. Jedności obserwowalnej w sztuce greckiej zabrakło w myśleniu. Jak wspomniałam wyżej, wysiłek Sokratesa, aby pogodzić dwa sposoby myślenia: mityczny - tradycyjny i nowy - racjonalny, a tym samym - dwie odseparowane od siebie grupy społeczne, zakończył się spektakularnym fiaskiem, które podział ten wysubtelniło i mimo wszystko pogłębiło. Według Deweya miało to dalsze reperkusje, nastąpiło wydzielenie dwóch aspektów rzeczywistości: niezmiennej i idealnej rzeczywistości metafizycznej od empirycznie doświadczalnej rzeczywistości życia codziennego. Filozofia zatem, zamiast zajmować się badaniem głównych cech życia i rzeczywistości (Dewey, 1925: 54), skupiła się na zajęciu w gruncie rzeczy nieciekawym i wtórnym w stosunku do rzeczywistości samej: zajęła się mianowicie próbą w miarę spójnego pogodzenia bytu idealnego i empirii. To wypaczyło filozofię Zachodu na wiele wieków. Dewey uważał, że dzielenie rzeczywistości i wertykalne jej hierarchizowanie jest błędne. Dla niego rzeczywistość była tylko jedna, a filozofia miała badać jej główne cechy. Ciągłość, kontynuacja to kolejne kluczowe pojęcia pragmatyzmu Deweya: filozofia, tak jak życie, jest ukształtowana linearnie i horyzontalnie. I w tym aspekcie ujawnia się ewolucjonistyczne myślenie Deweya.

\section{5.}

Dlaczego filozofia Deweya w wersji pierwotnej miałaby być dzisiaj dla nas interesująca? Przede wszystkim dlatego, że Dewey proponuje ujęcie życia ludzkiego jako całości, myśli o nim i o filozofii zawsze jako o linearnej i ciągłej całości za- 
leżnej od kontekstu kulturowego. W czasach, kiedy cywilizacja wymusza na nas dzielenie poszczególnych aspektów życia i jaźni (w psychologii wyróżnia się już kilka rodzajów inteligencji: emocjonalną, społeczną, seksualną), Dewey pokazuje zalety płynące z całościowego i spójnego myślenia o naszym życiu. Człowiek jest psychofizyczną całością. Co więcej, Dewey uświadamia nam, że tylko my możemy uczynić nasze życie lepszym, mądrzejszym. My sami najlepiej wiemy, jak zaspokoić nasze potrzeby i jakiego one są rodzaju, i tylko my potrafimy odnaleźć nasz wewnętrzny rytm zagubiony w chaosie podzielonego życia, który to rytm doprowadzi nas do spełnienia.

W drugim rzędzie Dewey z siłą uświadamia nam, czym jest sztuka żywa i aktualna. Wyrasta ona z rytmu i potrzeb życia społecznego, stanowi wyraz przekonań społeczności czy społeczeństwa. Jako że przekonania wyrażone mają konkretne znaczenia dla ich wyznawców, zaspokajają tym samym potrzeby estetyczne, czyli potrzeby odczuwania życia i naszego w nim wzrastania. Sztuka zamknięta w muzach rzadko, bardzo rzadko ma znaczenie dla szerokich rzesz społecznych. Głównie spełnia ona wysublimowane potrzeby garstki amatorów, ekspertów, uczniów. Nie znaczy to jednak, że masy społeczeństwa realizują swoje potrzeby estetyczne tylko i wyłącznie oglądając telenowele bądź słuchając muzyki rozrywkowej - choć w ten sposób oczywiście też. Zastanówmy się, jakie obiekty, produkty sztuki mogą przyczyniać się odzyskania kontaktu z życiem, do powstania przeżyć znaczących, do obudzenia w ludziach zdolności do skupienia i szerszej refleksji. Jakie obiekty sprawią, że ludzie wejdą z nimi bądź z innymi ludźmi przy ich pomocy w istotną dla nich interakcję, która stanie się szczególnym rodzajem doświadczenia, ubogacającego ich życie?

Przychodzą mi na myśl budowle dość kontrowersyjne z różnych powodów. Wydaje się jednak, że świątynia Opatrzności Bożej, wybudowana ostatnio, zaspokaja nie tylko religijne potrzeby wierzących, ale również inne potrzeby, w tym stricte estetyczne (budowniczy i architekci zadbali o symbolikę budowli, ma ona 365 okien itd. Ten konceptualizm nasuwa skojarzenia z barokowym zamkiem Krzyżtopór Ossolińskich w Ujeździe). Rozmach budowli, nawiązania i cytaty z innych znanych budowli sakralnych, symbolika i eklektyzm świątyni sprawiają, że określić ją możemy nawet jako postmodernistyczną - choć to jest raczej propozycja interpretacyjna niż kategoryczne orzeczenie. Jest ona powodem do dumy dla katolików, jest miejscem, do którego się pielgrzymuje, a znane osoby na stronach internetowych opowiadają o znaczeniu, jakie dla ich życia owa świątynia posiada. Innymi słowy, znaczenie społeczne i estetyczne tego obiektu jest duże. 
Wynika ono z tego, że budowla powstała jako wyraz autentycznego zaangażowania w określone sprawy wielu ludzi i jest im potrzebna. Pełni podobną (niestety, nie obywatelską) funkcję do ateńskiego Partenonu, jakkolwiek może brzmieć to obrazoburczo dla niektórych.

Inny przykład, jaki mi się nasuwa, to Muzeum Powstania Warszawskiego. Jego twórcy użyli środków najbardziej oddziałujących na odbiorców: wizualizacji i dźwięku. Oglądanie ekspozycji pozwala poczuć się jak w roku 1944. Zainteresowanie społeczne Muzeum jest ogromne. Częściowo jest to spowodowane faktem, że kwestia powstania warszawskiego jest żywym problemem, nadal szeroko dyskutowanym, wzbudzającym spory i namiętności. Ambicją twórców była nie tyle rekonstrukcja i rewitalizacja problemu (jest to niepotrzebne, gdyż pamięć o powstaniu warszawskim jest ciągle żywa), co unaocznienie, które pozwala znaleźć się w środku zdarzeń. (Takie podejście do historii wzbudza wiele kontrowersji.) Co więcej, poszczególne ekspozycje są dostępne w Internecie (stało się tak na prośbę kombatantów, którzy nie mogą do Warszawy przyjechać) i każdy może dopisać do wizualizowanych zdarzeń czy przedmiotów swój komentarz, interpretację itd. Można również podzielić się nowymi informacjami historycznymi. Wszystkie wpisy internetowe są weryfikowane przez historyków i, jeśli zostaną przez nich zaakceptowane, są włączane do Muzeum. Idea Muzeum Powstania Warszawskiego opiera się zatem na modelu interakcyjnym. Ludzie współtworzą jego ekspozycję. Poza tym poznawanie historii nie jest oparte na oglądaniu czy słuchaniu, a na uczestniczeniu w niej. Historia zatem zostaje włączona w żywy nurt życia.

Te dwa przykłady są naturalnym wykwitem życia społecznego. Dewey walczył z alienacją sztuki od kontekstu, w którym powstała, w którym była wykorzystywana, używana, stosowana. Sztuka ma swoje oblicze użytkowe - najpiękniejsze greckie rzeźby były posągami w świątyniach i pełniły funkcje sakralne. U Deweya oddzielanie sztuki od jej funkcji jest wyrywaniem jej z kontekstu i ograbianiem ze znaczenia. Dzisiejsze greckie rzeźby zamknięte w muzeach mówią nam coś o proporcjach i o klasycznym pięknie itd. Jakby powiedział słynny oponent Deweya, Kuspit - stanowią wytchnienie od chaosu świata dzisiejszego. Prawda jest jednak taka, że te produkty sztuki (rzeźby), wyrwane z kontekstu, nie mówią prawdy o sobie, bo nie widzimy tej sztuki, taką jaką ona była, tylko widzimy taką, jaką ona jest dla nas dzisiaj. Podobnie dzieje się z dziełami z innych epok: co nam może powiedzieć rzeźba plemion afrykańskich z British Museum? Nic. Jest dla nas obca, egzotyczna i przez to atrakcyjna, ale nie mówi nic o do- 
świadczeniu estetycznym, do którego powstania się przyczyniała. Teraz jest tylko przedmiotem sztuki.

Nie ulega wątpliwości, że Dewey ma nam dzisiaj coś ważnego do powiedzenia: każda społeczność ludzka tworzy sztukę, oczywiście na miarę swoich możliwości, która jest dla niej żywotna i znacząca. Podane powyżej przykłady wskazują na to, jakie istotne produkty o jakościach estetycznych tworzy społeczeństwo polskie. Świątynia Opatrzności Bożej, bazylika w Licheniu, Muzeum Powstania Warszawskiego - te dzieła tworzą sferę sztuki Polaków doby dzisiejszej. Zadaniem estetyki pragmatycznej jest mówienie o tym.

Podsumowując, można stwierdzić, że Dewey interesować nas może w dwóch zasadniczych kwestiach: w uświadomieniu nam, że tylko my, a nie eksperci, i nasze najbliższe otoczenie może zdecydować o tym, czy nasze życie będzie satysfakcjonujące. W kwestii drugiej Dewey przekonuje, ze sztuka to nie tylko przeżycia wysublimowanych estetów, ale że w dobie społeczeństw masowych ludzie potrafią stworzyć i przeżyć dla siebie coś ważnego. Nawet jeśliby to nie budziło aprobaty wspomnianych estetów.

\section{Literatura}

Brandon R. (2006). Singer i maszyna do szycia. Miłość, marzenia i kapitalizm, tłum. M. Latkowska. Warszawa.

Dewey J. (1925). Experience and Nature. Chicago.

Dewey J. (1975). Sztuka jako doświadczenie, tłum. A. Potocki. Wrocław.

Dewey J. (1988). Changing Conceptions of Philosophy. [W:] J. Dewey. Reconstruction in Philosophy and Essays, Middle Works, 1899-1924, vol. 12. Carbondale.

Hadot P. (1992). Filozofia jako ćwiczenie duchowe, tłum. P. Domański. Warszawa.

Hickman L. (2007). John Dewey's Twenty-First Century Global Outreach. www. deweycenter.uj.edu.pl

James H. (2004). Pragmatyzm. Nowa nazwa kilku starych metod myślenia, tłum. M. Filipczuk. Kraków.

Kaczocha W. (1987). Koncepcja filozofii kultury Johna Deweya. „Przegląd Humanistyczny” 10.

Shusterman R. (2005). Praktyka filozofii, filozofia praktyki, tłum. A. Mitek. Kraków.

Szymańska B. (1997). Co to znaczy być sobą? Filozoficzne aspekty pojęcia samorealizacji. Kraków.

Wilkoszewska K. (1991). Sztuka jako rytm życia. Kraków. 